\title{
S100P Expression in response to sex steroids during the implantation window in human endometrium
}

\author{
Dan Zhang ${ }^{1}$, Chengbin $\mathrm{Ma}^{2}$, Xiaoli Sun ${ }^{1}$, Hexia Xia ${ }^{1}$ and Wei Zhang ${ }^{1 *}$
}

\begin{abstract}
Background: S100P, a protein originally detected in the human placenta, has been found to play an important role in the development and invasion of tumors. Interestingly, we have recently discovered using data mining that S100P was considerably up-regulated during the window of implantation in the human endometrium, but little further information has been available.

Methods: Real-time PCR and immunofluorescence were performed to examine the expression and location of S100P in the human endometrium and endometrial cells. Estrogen and progesterone were added to the cultured cells to test the response of S100P to sex steroids.

Results: A dramatic peak, approximately a 100-fold increase in comparison with the proliferative and early-and late-secretory phases, was observed in the endometrium during the mid-secretory phase, which corresponds to the time of embryo implantation. Progesterone regulated the expression of S100P in both primary endometrial epithelial and stromal cells, but estrogen had no significant effect.

Conclusions: The results indicate that S100P participates in the periodic change of the endometrium under the regulation of progesterone, may be used as a unique biomarker of the receptive endometrium and play an important role in embryo implantation.
\end{abstract}

Keywords: Calcium-binding protein S100P, Endometrial receptivity, Hormonal regulation

\section{Background}

Embryo implantation is a bottleneck that limits successful pregnancy. A receptive endometrium and viable blastocyst are the two necessary conditions of successful implantation [1]. The endometrium is receptive only during the window of implantation, which lasts approximately four days (day 20-23), and occurs in humans during the mid-secretory phase in a normal 28-day menstrual cycle [2]. During the window of implantation, the endometrium undergoes extensive morphological and physiological changes to facilitate implantation of the embryo, including becoming more vascular and edematous with the glands displaying enhanced secretory activity [3]. This process is precisely regulated. Among all the

\footnotetext{
* Correspondence: zhang.wei.fudan@gmail.com

'Institute of Obstetrics and Gynecology Hospital, Fudan University, Shanghai, China

Full list of author information is available at the end of the article
}

regulating elements, reproductive hormones are the leading factors.

Recently, investigators have made great efforts to elucidate the molecular mechanisms of endometrial receptivity, and they have pursued biomarkers to identify the receptive endometrium. Previously, we employed bioinformatics to mine the existing microarrays and acquired a group of potential biomarkers [4], among them S100P attracted our attention.

S100P, originally isolated from the placenta, is a member of the family of S100 small molecular weight (9-14 $\mathrm{kDa})$ calcium-binding proteins, which are mainly implicated in calcium sensing and signal transduction [5]. Recent studies have shown that S100P is highly expressed in many types of tumors [6-14] and influences proliferation, invasion, survival, metastasis, angiogenesis and resistance to chemotherapy drugs in a diverse group of tumors [14-19]. In our previous work using data

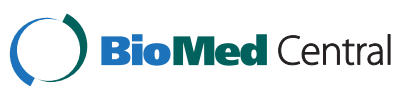


mining, we found extremely high expression of S100P during the window of implantation, and a few other microarray studies have also shown the same upregulation of S100P in $\mathrm{LH}+7$ or in the mid-secretory phase with a 6- to 20-fold change [20-22].

It has long been observed that there are strikingly similar biological processes between embryo implantation and tumor development and that the biological processes of proliferation, invasion, survival and angiogenesis are of crucial significance to a receptive endometrium and embryo implantation [23]. Thus, S100P might play an important role in the establishment of endometrial receptivity and embryo implantation.

The cyclical change of the endometrium is precisely controlled by reproductive hormones from the hypothalamus-pituitary-ovary axis. Studies of patients with premature ovarian failure (POF) have shown that $\mathrm{E}_{2}$ and $\mathrm{P}_{4}$ given sequentially can induce the establishment of endometrial receptivity, which indicates that $E_{2}$ and $\mathrm{P}_{4}$ are the dominant factors as well as the only necessary factors that control the establishment of endometrial receptivity $[24,25]$.

In a natural cycle, the granulosa cells of the developing follicle produce $E_{2}$ in response to gonadotropin stimulation. Adequate $E_{2}$ priming of the endometrium results in endometrial proliferation and the induction of sufficient $\mathrm{P}_{4}$ receptors to allow subsequent $\mathrm{P}_{4}$ stimulation for endometrial receptivity. In response to $\mathrm{P}_{4}$, the endometrium undergoes profound conformational and biochemical changes, from proliferative to secretory, with a concomitant induction of endometrial receptivity and the opening of the window of implantation. Steroid hormones act by regulating the expression of their downstream effectors [24].

Therefore, in the present study, we designed experiments to verify the expression and location of S100P in the human endometrium during the menstrual cycle, and we further investigated the regulation of S100P by $\mathrm{E}_{2}$ and $\mathrm{P}_{4 .}$

\section{Methods}

\section{Sample collection}

The endometrial samples $(\mathrm{n}=24)$ were obtained via a pipelle catheter from fertile women, who provided informed consent under a protocol approved by the Committee of Fudan University Obstetrics and Gynecology Hospital on the Use of Human Subjects in Medical Research. Healthy volunteers or patients who were pathologically confirmed to have benign cervical lesions, aged 24 to 40 , had regular cycles (27-33 d), and had not taken steroid hormone medications within 3 months were enrolled in the study.

Eighteen of the samples were kept on ice and were immediately transported to the laboratory. Some portions of the samples were routinely embedded in optimal cutting temperature (OCT) compound, and the frozen blocks were subjected to hematoxylin and eosin staining or immunofluorescence staining. The histological evaluation was blindly conducted by two independent pathologists. The specimens were classified according to the criteria of Noyes et al. [26] as proliferative phase (d8-14, $\mathrm{n}=6)$, early-secretory phase $(\mathrm{d} 15-18, \mathrm{n}=4)$, midsecretory phase $(\mathrm{d} 19-23, \mathrm{n}=5)$, and late-secretory phase $(\mathrm{d} 24-28, \mathrm{n}=3)$. The other specimens were snap-frozen in liquid nitrogen for RNA and protein isolation.

Another six samples (mid- or late-proliferative phase) were transported to the laboratory for primary cell isolation.

\section{Culture of primary cells}

The six samples were mixed together for cell isolation. Isolation of primary endometrial epithelial and stromal cells (EECs and ESCs) was performed as described previously [27] with some modifications. The endometrial tissues were minced $\left(<0.1 \mathrm{~mm}^{3}\right)$ before being digested via incubation in Dulbecco's minimum essential medium (DMEM)/F-12 containing $0.25 \%$ type II collagenase (Sigma, St. Louis, MO) at $37^{\circ} \mathrm{C}$ for $1 \mathrm{~h}$. The dispersed endometrial cells were separated into ESCs and EECs by filtration through a nylon cell strainer with 40-um pores. The filtered ESCs were centrifuged and plated in DMEM/F-12 containing $10 \%$ fetal bovine serum (Gibco, Australia) in $100-\mathrm{mm}$ culture dishes. At the first passage, they were placed on 6-well dishes at a density of $5 \times 10^{5}$ cells per well. Those that had reached confluence in 2 or 3 days were used for the experiments.

Unfiltered glands were rinsed with more than $30 \mathrm{ml}$ of PBS before being back-flushed from the sieves. After centrifuging, the EECs were planted on $35-\mathrm{mm}$ culture dishes at a density of $4 \times 10^{5}$ cells per well using the same medium. Any ESCs remaining with EECs were further separated by selective adherence to culture dishes for $1 \mathrm{~h}$. The cells that reached confluence in 2 or 3 days were used for the experiments. The purity of both stromal and epithelial cells was achieved by over $95 \%$, as determined by cellular staining with vimentin and cytokeratin (See Additional file 1, Figure S1).

\section{Hormonal stimulation protocol}

Cultured cells with a number of $1 \times 10^{5}$ were placed in $1 \mathrm{ml}$ of medium and seeded into a 12-well plate, and cultured cells with a number of $1 \times 10^{4}$ were placed in $200 \mu \mathrm{l}$ of medium and seeded into a 96-well plate. Both were subjected to 24-hour culture to achieve $50 \%$ confluence in normal medium containing $10 \%$ FBS. The half-confluent monolayers were maintained in serumfree media for $48 \mathrm{~h}$ prior to hormonal stimulation. We 
first treated the cells with 17beta-estradiol (Sigma, USA) at $10^{-8} \mathrm{~mol} / \mathrm{L}$, Progesterone (Sigma, USA) at $10^{-7}$ and $\mathrm{E}_{2}$ combined with $\mathrm{P}_{4}\left(10^{-8} \mathrm{~mol} / \mathrm{L} \mathrm{E}_{2}\right.$ with $\left.10^{-7} \mathrm{~mol} / \mathrm{L} \mathrm{P}_{4}\right)$ for $48 \mathrm{~h}$ to test the response of S100P to reproductive hormones. And then we chose $\mathrm{P}_{4}$ and stromal cells to proceed the time and dose course experiments, treating stromal cells with different concentrations of $\mathrm{P}_{4}\left(10^{-7}\right.$, $10^{-8}$ and $\left.10^{-9} \mathrm{~mol} / \mathrm{L}\right)$ for $48 \mathrm{~h}$ or $\mathrm{P}_{4}\left(10^{-7} \mathrm{~mol} / \mathrm{L}\right)$ for different periods of time $(24,48$ and $72 \mathrm{~h})$. The hormonally treated cells that were seeded in 12-well plates were collected for real-time reverse transcriptase-polymerase chain reaction (real-time PCR) analysis, and those seeded in 96-well plates were fixed for in-cell Western analysis.

\section{RNA isolation and real-time PCR analysis}

Total RNA was isolated using Trizol reagent (Invitrogen, USA) and the cDNA generated using the RevertAidTM First Strand cDNA Synthesis Kit (Fermentas, Canada) according to the manufacturer's protocol.

Quantitative PCR reactions were carried out with SYBR Premix Ex Taq (Takara) and detected with an Applied Biosystem PRISM 7500HT system. The expression of S100P was normalized to that of the beta-actin in all samples. The primers were designed using the software Primer3 [28] as follows:

\section{S100P, forward 5'TACCAGGCTTCCTGCAGAGT-3' reverse 5'-AGGGCATCATTTGAGTCCTG-3'; \\ beta-actin, forward 5'- \\ CGGGACCTGACTGACTACTCA-3' \\ reverse 5'-TCAAGAAAGGGTGTAACGCAACTA -3'.}

All experiments were performed in triplicate.

\section{Tissue immunofluorescence}

Endometrial biopsies were embedded in optimum cutting temperature compound (Tissue-Tech, Sakura Finetechnical, Japan), snap-frozen, and cut into 5- $\mu \mathrm{m}$ thick sections. After fixation in cold acetone for $30 \mathrm{~min}$, the sections were incubated with $5 \%$ bovine serum albumin (BSA) for 30 minutes at room temperature. Afterwards, they were incubated with mouse anti-human S100P ( $R \& D$, diluted 1:50 in phosphate-buffered saline PBS) for $2 \mathrm{~h}$ at $37^{\circ} \mathrm{C}$. After three 10 -minute washes in PBS, the sections were incubated with cy3-labeled goat antimouse IgG (Invitrogen) at 1:500 for $1 \mathrm{~h}$ at room temperature. The same washing procedures were performed, and the nuclei were counterstained with Hoechst33258 stain (Sigma) at $1 \mathrm{mg} / \mathrm{ml}$. The cells were then observed under a fluorescence microscope (Axiovert 200, Zeiss, Germany).

\section{Cellular immunofluorescence staining}

To further observe the intracellular location of S100P in the endometrial cells, immunofluorescence staining for S100P was performed on cell climbing slices. Cell climbing slices were placed on the bottom of 6-well dishes before seeding the first passage cells, which were maintained in DMEM/F-12 containing 10\% fetal bovine serum. The slices were removed when the cells reached $50 \%$ confluence, and they were fixed in $3.7 \%$ formaldehyde for $20 \mathrm{~min}$ before being permeabilized and blocked using PBS containing 0.1\% Triton X-100 (Sigma) and 5\% $\mathrm{BSA}$ at $37^{\circ} \mathrm{C}$ for $45 \mathrm{~min}$. The slices were incubated overnight at $4^{\circ} \mathrm{C}$ with 1:50 mouse anti-human S100P monoclonal antibody (R\&D Systems, Minneapolis, MN) diluted in blocking buffer. They were washed three times in PBS for $5 \mathrm{~min}$ and incubated with 1:500 cy3-labeled goat anti-mouse IgG (Invitrogen) for $1 \mathrm{~h}$ at room temperature. The same washing procedures were performed again, and the nuclei were counterstained with Hoechst33258 stain (Sigma) at $1 \mathrm{mg} / \mathrm{ml}$. The cells were observed under the same fluorescence microscope (Axiovert 200, Zeiss, Germany).

\section{In-cell western}

In-cell Western, an immunocytochemical assay to quantify proteins in fixed cells [29], was performed to evaluate the protein level changes of S100P after hormonal treatment. The cells were seeded in 96-well plates, and treatments were performed as described above. The medium was removed, the cells were fixed in $200 \mu \mathrm{l}$ of $3.7 \%$ formaldehyde in PBS for $20 \mathrm{~min}$, and they were permeabilized and blocked using $200 \mu \mathrm{l}$ PBS containing $0.1 \%$ Triton $\mathrm{X}-100$ and $5 \% \mathrm{BSA}$ at $37^{\circ} \mathrm{C}$ for $45 \mathrm{~min}$. Afterwards, they were incubated overnight at $4^{\circ} \mathrm{C}$ with 1:50 mouse anti-human S100P monoclonal antibody (MAB2957, R\&D Systems) and 1:200 rabbit anti-human beta-actin antibody (1854-1, Epitomics, USA) diluted in blocking buffer. They were washed three times with PBS for 5 minutes, and the dishes were incubated with 1:1000 fluorescently labeled IRDye 800 anti-mouse and IRDye 680 anti-rabbit secondary antibodies (KPL, USA) for $1 \mathrm{~h}$ at room temperature, followed by the same washing procedures. The negative controls were obtained by omitting the primary antibodies. The intensity of cellular staining was quantified by densitometry using an Odyssey infrared imaging system (Li-Cor Biosciences). The specificity of the primary antibodies has been validated by Western blot prior to the experiments (See Additional file 2, Figure S2).

\section{Statistical analysis}

The results are presented as the means $\pm \mathrm{SD}$ of three to six independent experiments. Statistical analyses were performed using one-way ANOVA, followed by LSD 
analysis using SPSS 15.0 software, and their values were considered statistically significant at $P<0.05$. All experiments were repeated at least three times.

\section{Results}

The mRNA expression of S100P in human endometrium The results of real-time PCR analysis showed that the mRNA expression of S100P was significantly up-regulated, with a peak in the mid-secretory endometium (MSE). The mRNA level in the MSE was 180 times as high as that in the proliferative endometrium (PE), 90 times as high as that in the early-secretory endometium (ESE) and over 70 times as high as that in the latesecretory endometium (LSE) $(P<0.01)$ (Figure 1$)$.

\section{The protein expression and tissue location of S100P in human endometrium}

Immunofluorescence was performed to detect the protein expression and location of S100P in the endometrium during the menstrual cycle. In comparison with the results of real-time PCR, the S100P protein expression presented the same moving pattern, where S100P signals were nearly undetected in the PE, slightly elevated in the ESE, dramatically enhanced in the MSE and sharply weakened in the LSE. In the MSE, the enhanced S100P signals were distributed in the glands and the stroma, but the highest immunoreactivity was located in the glands (Figure 2).

\section{The cellular location of S100P in endometrial cells}

The cellular immunofluorescence staining was conducted to observe the intracellular distribution of S100P.

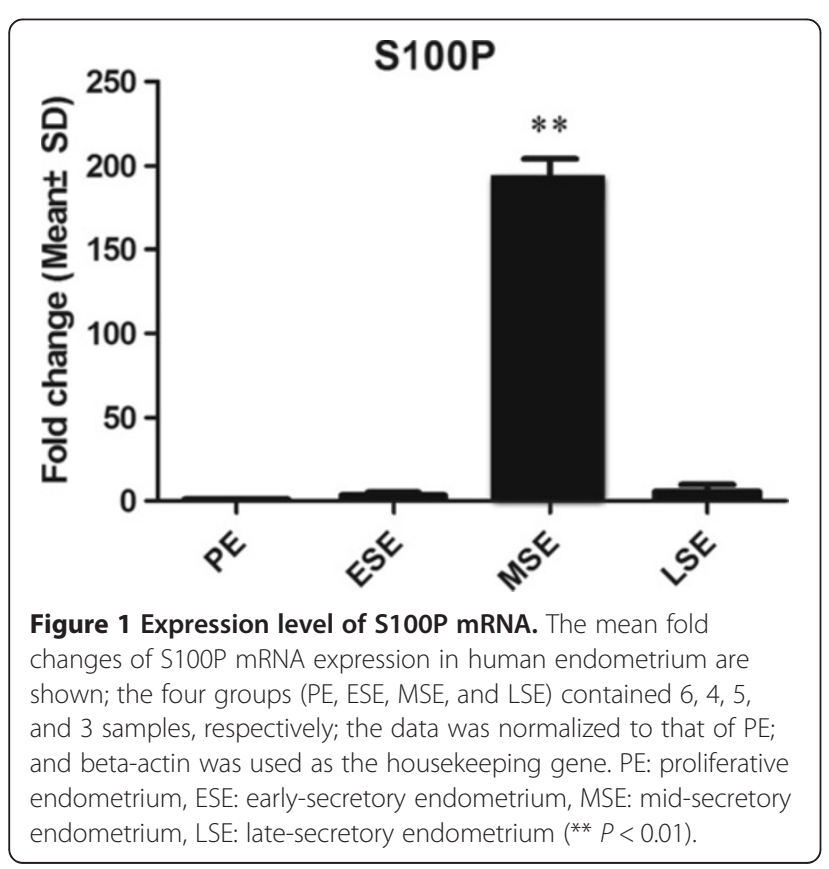

In the cultured primary endometrial epithelial and stromal cells, S100P was expressed in both the cytoplasm and the nucleus, although the signal intensity showed no significant difference between the cytoplasm and the nucleus (Figure 3).

\section{Regulation of S100P by reproductive hormones in human} endometrium

We first observed the hormonal effects on S100P after $48 \mathrm{~h}$ of stimulation with the highest physiological dose $\left(\mathrm{E}_{2}, 10^{-8} \mathrm{~mol} / \mathrm{L}\right.$ and $\left.\mathrm{P}_{4}, 10^{-7} \mathrm{~mol} / \mathrm{L}\right)$. In the primary epithelial and stromal cells, the expression of S100P was found to be strongly stimulated by $\mathrm{P}_{4}$, and its expression rose 4-fold in EEC and 20-fold in ESC at both the mRNA and protein level $(P<0.001) . E_{2}$ alone showed no obvious effects, and $\mathrm{E}_{2}$ combined with $\mathrm{P}_{4}$ did not display marked synergistic effects (Figure 4). Then, we further studied the time and dose effect of $\mathrm{P}_{4}$ on S100P in primary stromal cells. The expression of S100P peaked after stimulation for $48 \mathrm{~h}$, and was maximized at $10^{-7} \mathrm{~mol} / \mathrm{L}$. (Figure 5).

\section{Discussion}

In the present study, we determined the peak expression of S100P during the implantation window in terms of both the mRNA and protein levels, which was approximately 100 times high as those in the other phases of endometrium during the menstrual cycle. On the one hand, it suggests that S100P could be chosen as a unique biomarker of receptive endometrium. Moreover, the most prominent S100P signal in the MSE were located in the glands, which was not in accordance with the expression pattern found by Tong et al. [30], who showed that S100P is distributed in the nuclei and observed more intense S100P immune staining in the stroma compared to that in the glands. However, our results were similar to those for the gastric mucosa reported by Parkkila et al., who reported that the highest immunoreactivity was located in the surface epithelial cells and glands [31], suggesting that S100P has the potential to be secreted into the uterine cavity and detected in the uterine fluid as a non-invasive biomarker of endometrial receptivity. On the other hand, it suggests that S100P could be functionally related to the establishment and withdrawal of endometrial receptivity, the secretory activity of the endometrium and the maintenance of the inter-uterine environment. It has been reported that the expression of S100P increased 37-fold in stromal cells after their co-culture with trophoblast cells [32], which proved that S100P might be involved in interactions at the maternal-fetal interface.

Previous studies have shown that S100P can be localized in the cytoplasm and/or the nucleus of a wide range of cells, and as a secretory protein, it can also be 


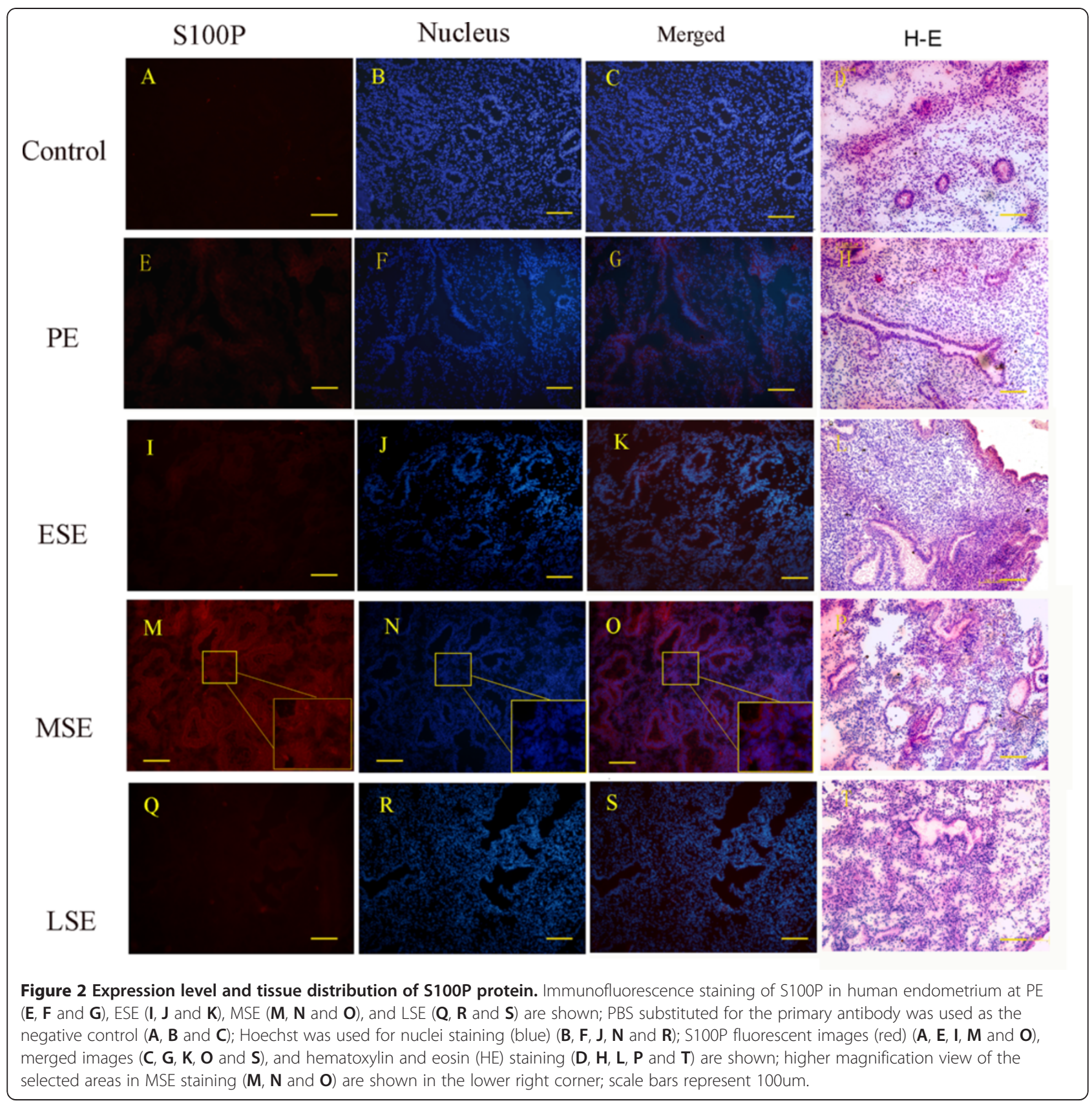

secreted to extracellular regions [13,31,33]. In the present study, we observed that S100P is expressed in the nucleus as well as in the cytoplasm of endometrial cells and that it largely accumulated in the cytoplasm of EECs and ESCs. The cellular location of S100P has been reported to correspond to its molecular functions as follows: the intracellular component of S100P could interact with Ezrin, a multi-domain link protein of the membrane-cytoskeleton, thus playing a role in cell differentiation, adhesion, and migration [34]; S100P in the cytoplasm could bind to CacyBP/SIP, a component of the ubiquitin pathway, which is involved in the degradation of the cell signaling molecule $ß$-catenin [35]; the extracellular-soluble form of S100P could function as a ligand of the RAGE receptor to modulate cell proliferation and survival via activation of MAP kinase and NF-kappa B pathway [10]; and the component of S100P in the nucleus might bind to S100PBP (S100P binding protein), the exact role of which remains unclear.

It has been shown that cell proliferation, adhesion and motility are all vital to endometrial receptivity and embryo implantation, in which ß-catenin [36], MAP kinase [37] and the NF-kappa B pathway [38] play an 

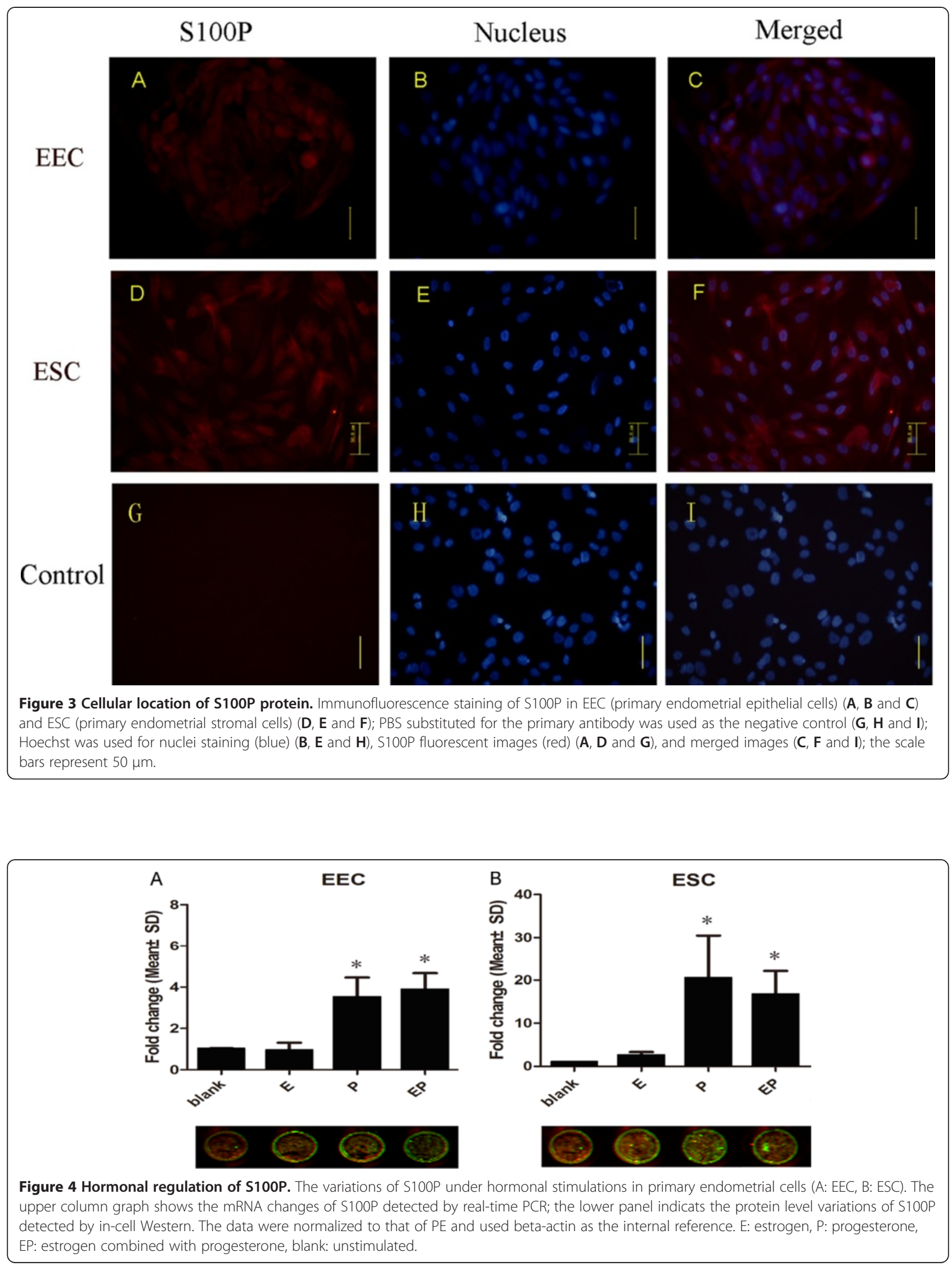


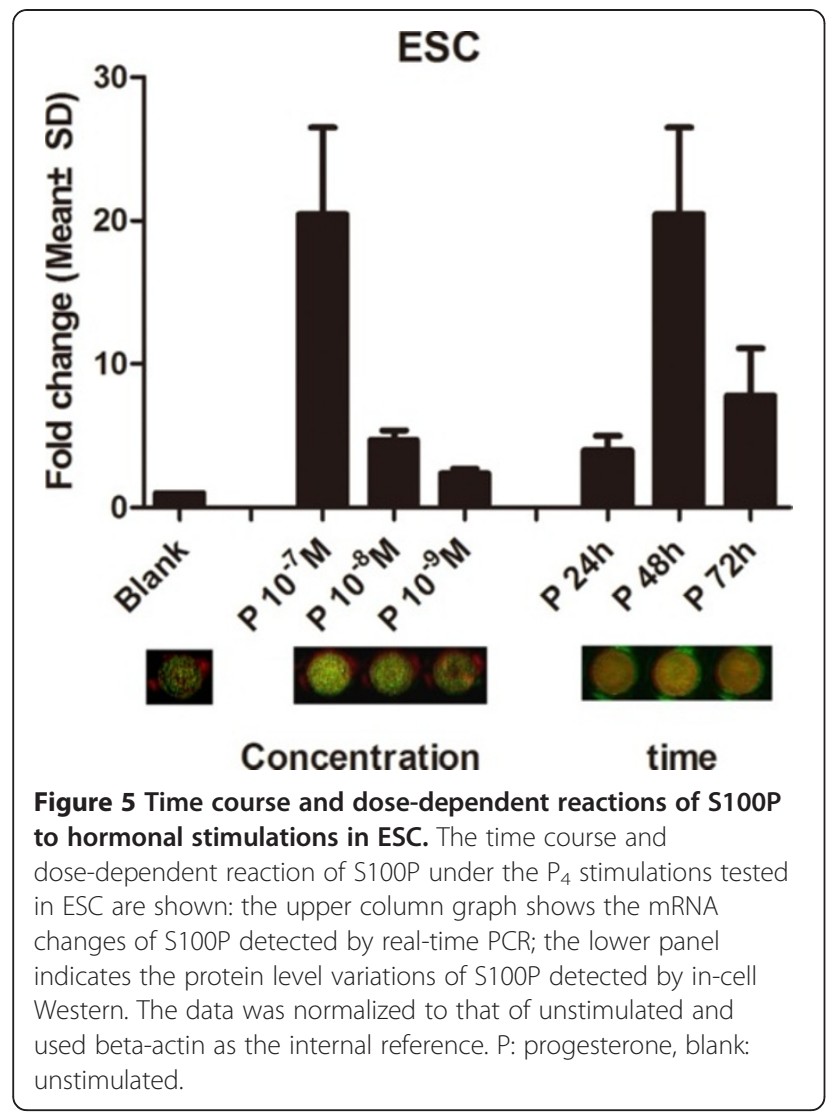

important role. Ezrin, which regulates the reorganization of cytoskeleton-membrane connections [39], has also been shown to be involved. These findings suggest that S100P might act as a key linker participating in the formation of endometrial receptivity and embryo implantation.

Elucidating the regulation of S100P is an important step towards understanding the biological significance of and proposing strategies for targeted S100P modulation [14]. Recent studies have shown that DNA methylation [40], IL-6 [41], bone morphogenic protein [42], prostaglandin E (PGE)/EP4 [43], glucocorticoid [44], and nonsteroidal anti-inflammatory drugs [45] could regulate S100P expression during tumor progression. Steroid hormones were also reported to play a role in the expression of S100P, including the synthetic androgen R1881, which regulates the expression of S100P in prostate cancer [46], as well as $\mathrm{P}_{4}$ and six other types of clinically relevant synthetic progestins, which up-regulate $\mathrm{S} 100 \mathrm{P}$ in progesterone receptor (PR)-positive cell lines of breast cancer [47].

In the present study, we verified that $\mathrm{P}_{4}$ can upregulate the expression of S100P in primary endometrial cells. The results of the time course experiments showed a parabolic shape, with a peak at $48 \mathrm{~h}$, after which a sharp drop was observed. The dose-dependent experiments showed that S100P expression increased with increasing $\mathrm{P}_{4}$ concentrations within a certain range. This response explained the special temporal expression of S100P during the window of implantation resulting from the influence of $\mathrm{P}_{4}$. The level of progesterone secretion may have peaked at the mid-secretory phase in concert with the peak value of S100P expression, and the expression of S100P may have declined significantly with the time extension of progesterone at the late-secretory phase, although the concentration of progesterone decreased little.

\section{Conclusions}

For the first time, we systematically clarified the expression and hormonal regulation of S100P in endometrial cells, and we found that its expression peaked during the window of implantation and that progesterone could function as effective regulators of S100P expression. The results indicate that S100P participates in periodic changes of the endometrium under the regulation of progesterone, that it might perform an important function in regulating endometrial development during the menstrual cycle and in developing conditions necessary for embryo implantation, and that it might be used as a unique biomarker of a receptive endometrium.

\section{Additional files}

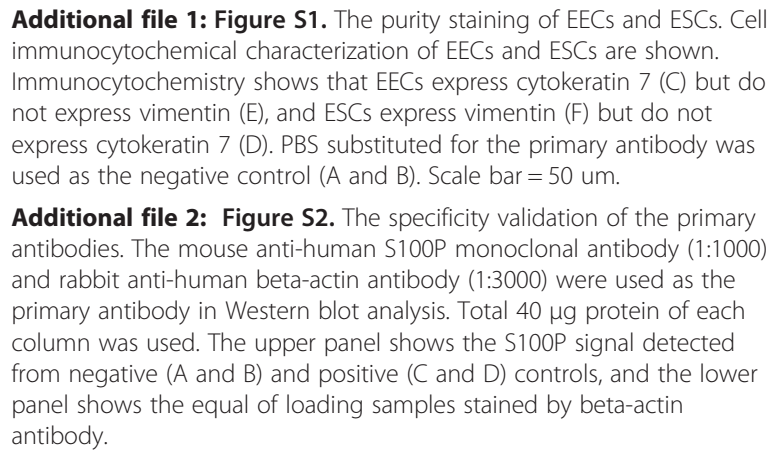

Additional file 2: Figure S2. The specificity validation of the primary antibodies. The mouse anti-human S100P monoclonal antibody (1:1000) and rabbit anti-human beta-actin antibody (1:3000) were used as the primary antibody in Western blot analysis. Total $40 \mu \mathrm{g}$ protein of each column was used. The upper panel shows the S100P signal detected from negative ( $A$ and $B$ ) and positive ( $C$ and $D)$ controls, and the lower panel shows the equal of loading samples stained by beta-actin antibody.

\section{Competing interests}

The authors declare that they have no competing interests with respect to the authorship and/or publication of this article.

\section{Authors' contributions}

DZ participated in the design of the study, collected the materials, carried out all experiments, and drafted the manuscript. DZ, HX, and XS collected the materials and helped maintain the cell culture. CM and WZ conceived of the study. WZ participated in its design and coordination and helped draft the manuscript. All authors read and approved the final manuscript.

\section{Acknowledgements}

We would like to thank the staff of the Department of Cervical Disease, Obstetrics and Gynecology Hospital, Fudan University for their assistance in sample collections. This work was supported by grants from the Shanghai Scientific and Technological Foundation for Innovations (No. 11411950100), the Shanghai Foundation for Pioneering Medical Projects (No. 10411960600) and the Shanghai Foundation for Outstanding Subject Leaders Projects (No.12XD1401200) 


\section{Author details}

${ }^{1}$ Institute of Obstetrics and Gynecology Hospital, Fudan University, Shanghai, China. ${ }^{2}$ Health Center for Women and Children, Chang ning district,

Shanghai, China.

Received: 24 July 2012 Accepted: 28 November 2012 Published: 7 December 2012

\section{References}

1. Achache $H$, Revel A: Endometrial receptivity markers, the journey to successful embryo implantation. Hum Reprod Update 2006, 12(6):731-746.

2. Wilcox AJ, Baird DD, Weinberg CR: Time of implantation of the conceptus and loss of pregnancy. N Engl J Med 1999, 340(23):1796-1799.

3. Salamonsen LA, Nie G, Hannan NJ, Dimitriadis E: Society for reproductive biology Founders' lecture 2009. Preparing fertile soil: the importance of endometrial receptivity. Reprod Fertil Dev 2009, 21(7):923-934.

4. Zhang D, Sun C, Ma C, Dai H, Zhang W: Data mining of spatial-temporal expression of genes in the human endometrium during the window of implantation. Reprod Sci 2012, 19(10):1085-1098.

5. Becker T, Gerke V, Kube E, Weber K: S100P, A novel Ca(2+)-binding protein from human placenta. CDNA cloning, recombinant protein expression and Ca2+ binding properties. Eur J Biochem 1992, 207(2):541-547.

6. Bulk E, Hascher A, Liersch R, Mesters RM, Diederichs S, Sargin B, Gerke V, Hotfilder M, Vormoor J, Berdel WE, Serve H, Muller-Tidow C: Adjuvant therapy with small hairpin RNA interference prevents non-small cell lung cancer metastasis development in mice. Cancer Res 2008 68(6):1896-1904

7. Abd El All H: Smooth muscle actin and s100p on non germinal centre diffuse large B cell lymphoma are adverse prognostic factors: pilot study. Diagn Pathol 2007, 2:9.

8. Amelung JT, Buhrens R, Beshay M, Reymond MA: Key genes in lung cancer translational research: a meta-analysis. Pathobiology 2010, 77(2):53-63.

9. Arumugam T, Ramachandran V, Logsdon CD: Effect of cromolyn on S100P interactions with RAGE and pancreatic cancer growth and invasion in mouse models. J Natl Cancer Inst 2006, 98(24):1806-1818.

10. Arumugam T, Simeone DM, Schmidt AM, Logsdon CD: S100P Stimulates cell proliferation and survival via receptor for activated glycation end products (RAGE). J Biol Chem 2004, 279(7):5059-5065.

11. Arumugam T, Simeone DM, Van Golen K, Logsdon CD: S100P Promotes pancreatic cancer growth, survival, and invasion. Clin Cancer Res 2005, 11(15):5356-5364.

12. Bartling B, Rehbein G, Simm A, Silber RE, Hofmann HS: Porcupine expression is associated with the expression of S100P and other cancer-related molecules in non-small cell lung carcinoma. Int J Oncol 2010, 36(4):1015-1021

13. Basu GD, Azorsa DO, Kiefer JA, Rojas AM, Tuzmen S, Barrett MT, Trent JM, Kallioniemi O, Mousses S: Functional evidence implicating S100P in prostate cancer progression. Int J Cancer 2008, 123(2):330-339.

14. Gibadulinova A, Tothova V, Pastorek J, Pastorekova S: Transcriptional regulation and functional implication of S100P in cancer. Amino Acids 2010, 41(4):885-892.

15. Hamada S, Satoh K, Hirota M, Kanno A, Ishida K, Umino J, Ito H, Kikuta K, Kume K, Masamune A, Katayose Y, Unno M, Shimosegawa T: Calcium-binding protein S100P is a novel diagnostic marker of cholangiocarcinoma. Cancer Sci 2011, 102(1):150-156.

16. Shiota $M$, Tsunoda $T$, Song $Y$, Yokomizo A, Tada $Y$, Oda $Y$, Naito $S$ : Enhanced S100 calcium-binding protein P expression sensitizes human bladder cancer cells to cisplatin. BJU Int 2010, 107(7):1148-1153.

17. Nakata K, Nagai E, Ohuchida K, Hayashi A, Miyasaka Y, Aishima S, Oda Y, Mizumoto K, Tanaka M, Tsuneyoshi M: S100P Is a novel marker to identify intraductal papillary mucinous neoplasms. Hum Pathol 2010, 41(6):824-831

18. Levy M, Lin F, Xu H, Dhall D, Spaulding BO, Wang HL: S100P, von hippellindau gene product, and IMP3 serve as a useful immunohistochemical panel in the diagnosis of adenocarcinoma on endoscopic bile duct biopsy. Hum Pathol 2010, 41(9):1210-1219.

19. Arumugam T, Logsdon CD: S100P: a novel therapeutic target for cancer. Amino Acids 2010, 41(4):893-899.

20. Riesewijk A, Martin J, van Os R, Horcajadas JA, Polman J, Pellicer A, Mosselman S, Simon C: Gene expression profiling of human endometrial receptivity on days $\mathrm{LH}+2$ versus $\mathrm{LH}+7$ by microarray technology. Mol Hum Reprod 2003, 9(5):253-264.

21. Diaz-Gimeno P, Horcajadas JA, Martinez-Conejero JA, Esteban FJ, Alama P, Pellicer A, Simon C: A genomic diagnostic tool for human endometrial receptivity based on the transcriptomic signature. Fertil Steril 2010, 95(1):50-60.

22. Talbi S, Hamilton AE, Vo KC, Tulac S, Overgaard MT, Dosiou C, Le Shay N, Nezhat CN, Kempson R, Lessey BA, Nayak NR, Giudice LC: Molecular phenotyping of human endometrium distinguishes menstrual cycle phases and underlying biological processes in normo-ovulatory women. Endocrinology 2006, 147(3):1097-1121

23. Murray MJ, Lessey BA: Embryo implantation and tumor metastasis: common pathways of invasion and angiogenesis. Semin Reprod Endocrinol 1999, 17(3):275-290.

24. Kodaman PH, Taylor HS: Hormonal regulation of implantation. Obstet Gynecol Clin North Am 2004, 31(4):745-766, ix.

25. Paulson RJ: Hormonal induction of endometrial receptivity. Fertil Steril 2011, 96(3):530-535.

26. Noyes RW, Hertig AT, Rock J: Dating the endometrial biopsy. Am J Obstet Gynecol 1975, 122(2):262-263.

27. Arnold JT, Kaufman DG, Seppala M, Lessey BA: Endometrial stromal cells regulate epithelial cell growth in vitro: a new co-culture model. Hum Reprod 2001, 16(5):836-845.

28. Primer3. http://frodo.wi.mit.edu.

29. Egorina EM, Sovershaev MA, Osterud B: In-cell western assay: a new approach to visualize tissue factor in human monocytes. $J$ Thromb Haemost 2006, 4(3):614-620.

30. Tong XM, Lin XN, Song T, Liu L, Zhang SY: Calcium-binding protein S100P is highly expressed during the implantation window in human endometrium. Fertil Steril 2010, 94(4):1510-1518.

31. Parkkila S, Pan PW, Ward A, Gibadulinova A, Oveckova I, Pastorekova S, Pastorek J, Martinez AR, Helin HO, Isola J: The calcium-binding protein $\mathrm{S} 100 \mathrm{P}$ in normal and malignant human tissues. BMC Clin Pathol 2008, 8:2.

32. Popovici RM, Betzler NK, Krause MS, Luo M, Jauckus J, Germeyer A, Bloethner S, Schlotterer A, Kumar R, Strowitzki T, von Wolff M: Gene expression profiling of human endometrial-trophoblast interaction in a coculture model. Endocrinology 2006, 147(12):5662-5675.

33. Whiteman HJ, Weeks ME, Dowen SE, Barry S, Timms JF, Lemoine NR, Crnogorac-Jurcevic T: The role of S100P in the invasion of pancreatic cancer cells is mediated through cytoskeletal changes and regulation of Cathepsin D. Cancer Res 2007, 67(18):8633-8642.

34. Koltzscher M, Neumann C, Konig S, Gerke V: Ca2 + -Dependent binding and activation of dormant ezrin by dimeric S100P. Mol Biol Cell 2003, 14(6):2372-2384

35. Filipek A, Jastrzebska B, Nowotny M, Kuznicki J: CacyBP/SIP, a calcyclin and siah-1-interacting protein, binds EF-hand proteins of the S100 family. J Biol Chem 2002, 277(32):28848-28852.

36. Chen Q, Zhang Y, Lu J, Wang Q, Wang S, Cao Y, Wang H, Duan E: Embryo-uterine cross-talk during implantation: the role of Wnt signaling. Mol Hum Reprod 2009, 15(4):215-221.

37. McKinnon T, Chakraborty C, Gleeson LM, Chidiac P, Lala PK: Stimulation of human extravillous trophoblast migration by IGF-II is mediated by IGF type 2 receptor involving inhibitory $\mathrm{G}$ protein(s) and phosphorylation of MAPK. J Clin Endocrinol Metab 2001, 86(8):3665-3674.

38. Nakamura H, Kimura T, Ogita K, Nakamura T, Takemura M, Shimoya K, Koyama S, Tsujie T, Koyama M, Murata Y: NF-kappaB activation at implantation window of the mouse uterus. Am J Reprod Immunol 2004, 51(1):16-21.

39. Heng S, Cervero A, Simon C, Stephens AN, Li Y, Zhang J, Paule S, Rainczuk A, Singh H, Quinonero A, Tapia A, Velasquez L, Salamonsen L, Rombauts L, Nie G: Proprotein convertase $5 / 6$ is critical for embryo implantation in women: regulating receptivity by cleaving EBP50, modulating ezrin binding, and membrane-cytoskeletal interactions. Endocrinology 2011, 152(12):5041-5052

40. Wang Q, Williamson M, Bott S, Brookman-Amissah N, Freeman A, Nariculam J, Hubank MJ, Ahmed A, Masters JR: Hypomethylation of WNT5A, CRIP1 and S100P in prostate cancer. Oncogene 2007, 26(45):6560-6565.

41. Hammacher A, Thompson EW, Williams ED: Interleukin- 6 is a potent inducer of $\mathrm{S} 100 \mathrm{P}$, which is up-regulated in androgen-refractory and metastatic prostate cancer. Int J Biochem Cell Biol 2005, 37(2):442-450. 
42. Hamada S, Satoh K, Hirota M, Fujibuchi W, Kanno A, Umino J, Ito H, Satoh A, Kikuta K, Kume K, Masamune A, Shimosegawa T: Expression of the calcium-binding protein $\mathrm{S100P}$ is regulated by bone morphogenetic protein in pancreatic duct epithelial cell lines. Cancer Sci 2009, 100(1):103-110.

43. Chandramouli A, Mercado-Pimentel ME, Hutchinson A, Gibadulinova A, Olson ER, Dickinson S, Shanas R, Davenport J, Owens J, Bhattacharyya AK, Regan JW, Pastorekova S, Arumugam T, Logsdon CD, Nelson MA: The induction of S100p expression by the prostaglandin E (PGE)/EP4 receptor signaling pathway in colon cancer cells. Cancer Biol Ther 2010, 10(10):1056-1066.

44. Kino T, Manoli I, Kelkar S, Wang Y, Su YA, Chrousos GP: Glucocorticoid receptor (GR) beta has intrinsic, GRalpha-independent transcriptional activity. Biochem Biophys Res Commun 2009, 381(4):671-675.

45. Namba T, Homan T, Nishimura T, Mima S, Hoshino T, Mizushima T: Up-regulation of S100P expression by non-steroidal anti-inflammatory drugs and its role in anti-tumorigenic effects. J Biol Chem 2009, 284(7):4158-4167.

46. Averboukh L, Liang P, Kantoff PW, Pardee AB: Regulation of S100P expression by androgen. Prostate 1996, 29(6):350-355.

47. Bray JD, Jelinsky S, Ghatge R, Bray JA, Tunkey C, Saraf K, Jacobsen BM, Richer JK, Brown EL, Winneker RC, Horwitz KB, Lyttle CR: Quantitative analysis of gene regulation by seven clinically relevant progestins suggests a highly similar mechanism of action through progesterone receptors in T47D breast cancer cells. J Steroid Biochem Mol Biol 2005, 97(4):328-341.

doi:10.1186/1477-7827-10-106

Cite this article as: Zhang et al:: S100P Expression in response to sex steroids during the implantation window in human endometrium. Reproductive Biology and Endocrinology 2012 10:106.

\section{Submit your next manuscript to BioMed Central and take full advantage of:}

- Convenient online submission

- Thorough peer review

- No space constraints or color figure charges

- Immediate publication on acceptance

- Inclusion in PubMed, CAS, Scopus and Google Scholar

- Research which is freely available for redistribution 